\title{
TINGKAT EFEKTIVITAS MEDIA PENYULUHAN USAHATANI KELAPA SAWIT KECAMATAN PANGKALAN KURAS KABUPATEN PELALAWAN
}

\section{Ria Resti Fauziah, Roza Yulida, Yulia Andriani}

Jurusan Agribisnis Fakultas Pertanian Universitas Riau

\author{
Jl. HR. Subrantas. Km 12.5 Simpang Baru Kode Pos 28293, Pekanbaru \\ Email : ria.resti20@gmail.com
}

\begin{abstract}
ABSTRAK
Tujuan dari penelitian ini adalah: 1) Menganalisis tingkat efektivitas ekstensi media pada kelapa sawit di kabupaten Pangkalan Kuras, 2) Menganalisis karakteristik hubungan petani terhadap tingkat efektivitas media di Pangkalan Kuras. Penelitian ini dilakukan di Desa Surya Indah dan Dundangan, Kecamatan Pangkalan Kuras, Kabupaten Pelalawan. Waktu penelitian dimulai dari bulan Maret hingga Desember 2018. Teknik pengambilan sampel yang akan digunakan dalam penelitian ini adalah metode purposive sampling. Total sampel yang diambil adalah 60 sampel. Metode analisis data yang digunakan untuk menjawab tujuan dalam penelitian ini adalah Deskriptif Kualitatif, Skala Likert, dan Korelasi Rank Spearman. Hasil penelitian menunjukkan bahwa: 1) Tingkat efektivitas ekstensi media yang dicetak termasuk dalam kategori "cukup efektif" pada ekstensi media dan efektivitas objek fisik termasuk dalam kategori "efektif". Ini menunjukkan bahwa penyuluh sebagai media objek fisik secara efektif digunakan di kabupaten Pangkalan Kuras. 2) Ada hubungan antara karakteristik petani dengan efektifitas internal dan eksternal media benda cetak atau fisik.
\end{abstract}

Kata kunci: minyak kelapa sawit, penyuluhan, efektivitas, media

\section{PENDAHULUAN}

Perkebunan merupakan subsektor yang berperan penting dalam perekonomian nasional melalui kontribusi dalam pendapatan nasional Provinsi Riau adalah salah satu provinsi di Indonesia yang memiliki potensi yang sangat baik untuk mengembangkan perkebunan kelapa sawit. Menurut Dinas Perkebunan Provinsi Riau (2016), Luas area perkebunan kelapa sawit dari tahun 2011-2015 mengalami peningkatan. Pada tahun 2015 luas area 2.424.545 Ha dengan produksi 7.841.947 Ton.

Perkembangan kelapa sawit di Provinsi Riau tidak terlepas dari perkembangan perkebunan kelapa sawit pada masing-masing daerah atau kabupaten/kota. Sentra perkebunan kelapa sawit terluas di Kabupaten Pelalawan adalah Kecamatan Pangkalan Kuras. Pada tahun 2017 Kecamatan Pangkalan Kuras memiliki luas area perkebunan kelapa sawit sebesar $17.602 \mathrm{Ha}$ dengan produksi

\section{0 | Tingkat Efektivitas Media Penyuluhan Usahatani Kelapa Sawit Kecamatan Pangkalan Kuras Kabupaten Pelalawan}


69.494 Ton dan produktivitas $4.000 \mathrm{~kg} / \mathrm{Ha}$ jumlah petani 5.862 orang (Dinas Perkebunan Kabupaten Pelalawan, 2018).

Penyuluhan pertanian adalah proses belajar dan mengajar dengan mengembangkan sistem pendidikan non formal secara efektif dan efisien dimana terjadinya perubahan perilaku dan karakteristik sasaran atau petani, tentu akan membutuhkan waktu yang relatif lama. Karakteristik petani dan penyuluh mempengaruhi dalam pelaksanaan penyuluhan. Pelaksanaan penyuluhan meliputi penyuluh, petani, media penyuluhan, metode penyuluhan, materi penyuluhan, tempat penyuluhan, dan waktu penyuluhan.

Pada dasarnya petani akan lebih memahami materi yang diberikan penyuluh dengan cara melihat, mendengar dan langsung mengerjakannya dengan cara mempraktekan di lapangan. Penyuluh dalam memberikan materi langsung ditujukan kepada anggota kelompoktani. Penyuluh memberikan materi yang dibutuhkan oleh pelaku usahatani yang sesuai dengan potensi desa binaan penyuluh.

Keberhasilan penyuluhan pertanian dipengaruhi oleh faktor internal dan faktor eksternal. Faktor internal adalah faktor atau daya dorong yang timbul dari diri sesorang, Sedangkan faktor eksternal yang dimaksud adalah faktor yang mendukung untuk melaksanakan usahatani yang timbul dari luar (Herzberg dalam Siagian, 2002).

Keefektifan media penyuluh pertanian yang penyuluh berikan kepada petani sawit di Kecamatan Pangkalan Kuras Kabupaten Pelalawan dapat ditandai dengan terjadinya perubahan sikap atau pendapat seseorang atau kelompok mengenai sebuah fenomena sosial, kemudian perubahan lainnya dibidang pertanian.

Permasalahan penelitian dapat dirumuskan sebagai berikut: 1). Bagaimana tingkat efektivitas media penyuluhan pada petani kelapa sawit di Kecamatan Pangkalan Kuras Kabupaten Pelalawan? 2). Bagaimana hubungan karakteristik internal dan eksternal petani terhadap tingkat efektivitas media penyuluhan usahatani kelapa sawit di Kecamatan Pangkalan Kuras Kabupaten Pelalawan?

Sesuai dengan rumusan masalah, maka tujuan yang hendak dicapai dalam melakukan penelitian ini adalah: 1). Menganalisis tingkat efektivitas media penyuluhan pada petani kelapa sawit di Kecamatan Pangkalan Kuras Kabupaten

\section{1 | Tingkat Efektivitas Media Penyuluhan Usahatani Kelapa Sawit Kecamatan Pangkalan Kuras Kabupaten Pelalawan}


Pelalawan, (2). Menganalisis hubungan karakteristik internal dan eksternal petani terhadap tingkat efektivitas media penyuluhan usahatani kelapa sawit di Kecamatan Pangkalan Kuras Kabupaten Pelalawan.

\section{METODE PENELITIAN}

Penelitian dilaksanakan di Kecamatan Pangkalan Kuras Kabupaten Pelalawan. Banyaknya penduduk yang bekerja disektor pertanian menunjukkan bahwa sumber daya alam setempat mendukung pelaksanaan kegiatan usahatani kelapa sawit. Penelitian ini di laksanakan dari bulan Desember 2017 sampai dengan Mei 2018.

Teknik pengambilan sampel yang akan digunakan dalam penelitian ini adalah metode purposive sampling atau pengambilan sampel secara sengaja dengan adanya kiteria yaitu kelompoktani terbanyak dan kelompoktani yang aktif dalam kegiatan usahatani kelapa sawit. Sementara untuk memperkecil ukuran sampel, sampel diambil menggunakan metode purposive sampling dimana pengurus kelompok tani seperti ketua, bendahara, dan sekretaris. Sisanya anggota kelompok tani yang aktif dalam kegiatan penyuluhan menggunakan metode random sampling.

Total sampel yang diambil adalah sebanyak 60 sampel dan jumlah tersebut mewakili seluruh sampel yang ada. Metode pengambilan sampel penyuluh yaitu menggunakan metode sensus. Metode pengumpulan data yang digunakan yaitu observasi dan wawancara baik dengan pertanyaan tertutup maupun pertanyaan terbuka.

Analisis deskriptif kualitatif yaitu menguraikan data-data yang diperoleh dilapangan, adapun tujuan dari metode ini adalah untuk melukiskan secara sistematis, factual dan akurat mengenai faktor-faktor sifat serta hubungan antar fenomena yang diselidiki.

\section{Analisis Skala Likerts Summated Rating Scale (LSRS) dan EPIC Model}

EPIC model dengan skala Likerts Summated Rating Scale (LSRS) dimana setiap pilihan jawaban-jawaban diberi skor. Pada penelitian ini, peneliti ingin melihat tingkat efektivitas media penyuluhan yang digunakan, maka untuk melihat tingkat

\section{2 | Tingkat Efektivitas Media Penyuluhan Usahatani Kelapa Sawit Kecamatan Pangkalan Kuras Kabupaten Pelalawan}


efektivitas media dilakukan analisis data dengan menggunakan EPIC model, diadopsi dari Durianto (2003) dalam Negara (2010) yang telah disesuaikan dengan kebutuhan penelitian. Skala likert adalah skala yang digunakan untuk mengukur persepsi, sikap atau pendapat seseorang atau kelompok mengenai sebuah peristiwa atau fenomena sosial, berdasarkan definisi operasional yang telah ditetapkan oleh peneliti (Akdon, 2007).

Tabel 1. Variabel dan indikator efektivitas pada EPIC model

\begin{tabular}{|c|c|c|c|}
\hline No. & Variabel & Indikator & Parameter \\
\hline 1. & Empathy & $\begin{array}{l}\text { a. Afeksi } \\
\text { b. Kognisi }\end{array}$ & $\begin{array}{l}\text { a. Afeksi : Ketertarikan dan } \\
\text { perasaan } \\
\text { b. Kognisi : Pendapat }\end{array}$ \\
\hline 2. & Persuation & a. Sikap dan perilaku & $\begin{array}{l}\text { a. Perubahan terhadap sikap dan } \\
\text { perilaku }\end{array}$ \\
\hline 3. & Impact & a. Pengetahuan & a. Peningkatan pengetahuan \\
\hline 4. & $\begin{array}{l}\text { Communicatio } \\
n\end{array}$ & $\begin{array}{l}\text { a. Kejelasan } \\
\text { informasi } \\
\text { b. Pemahaman }\end{array}$ & $\begin{array}{l}\text { a. Tingkat kejelasan } \\
\text { b. Tingkat pemahaman }\end{array}$ \\
\hline
\end{tabular}

Sumber: Durianto, 2003 dalam Negara, 2010

Tabel 2. Kategori efektivitas media

\begin{tabular}{llc}
\hline No. & Skor & Tingkat Efektivitas Media \\
\cline { 2 - 3 } & Kategori & Kategori Nilai Skala \\
\hline 1. & Kurang efektif & $1,00-1,65$ \\
2. & Cukup efektif & $1,66-2,31$ \\
3. & Efektif & $2,32-3,00$ \\
\hline
\end{tabular}

\section{Analisis Korelasi Rank Spearman}

Metode ini digunakan untuk mengukur tingkat atau eratnya hubungan antara dua variabel yang berskala ordinal, mengetahui tingkat kecocokan dari dua variabel

\section{3 | Tingkat Efektivitas Media Penyuluhan Usahatani Kelapa Sawit Kecamatan Pangkalan Kuras Kabupaten Pelalawan}


terhadap grup yang sama dan mengukur data kuantitatif secara eksakta sulit dilakukan misalnya mengukur tingkat kesukaan, produktivitas pegawai, tingkat motivasi dan lain-lain. (Riduwan, 2011).

Kriteria yang menunjukkan kuat atau lemahnya korelasi menurut Riduwan (2011)

Tabel 3. Nilai koefisien korelasi dan tingkat hubungan

\begin{tabular}{lll}
\hline No & Nilai Koefisien Korelasi & Tingkat Hubungan \\
\hline 1 & $0,000-0,199$ & Sangat Rendah \\
2 & $0,200-0,399$ & Rendah \\
3 & $0,400-0,599$ & Sedang \\
4 & $0,600-0,799$ & Kuat \\
5 & $0,800-1,000$ & Sangat Kuat \\
\hline Sumber: Riduwan (2011)
\end{tabular}

\section{HASIL DAN PEMBAHASAN}

\section{Keadaan Umum Tempat Penelitian}

Kecamatan Pangkalan Kuras merupakan salah satu Kecamatan dari 12 Kecamatan yang ada di wilayah Kabupaten Pelalawan terletak lebih kurang $45 \mathrm{Km}$ dari pusat Ibukota Kabupaten Pelalawan. Kecamatan Pangkalan Kuras memiliki luas wilayah sebesar $847.37 \mathrm{Km}^{2}$ dengan koordinat 0,1359 LS dan 102,0722 BT. Masingmasing desa dan kelurahan memiliki luas wilayah yang berbeda-beda dan berada di luar hutan .

Kecamatan Pangkalan Kuras memiliki batas-batas wilayah sebagai berikut: Sebelah Utara berbatasan dengan Kecamatan Pangkalan Kerinci atau Ibukota Kabupaten Pelalawan. Sebelah Selatan berbatasan dengan Kecamatan Pangkalan Lesung. Sebelah Timur berbatasan dengan Kecamatan Bunut dan Kecamatan Bandar Petalangan. Sebelah Barat berbatasan dengan Kecamatan Langgam.

\section{Karakteristik Responden}

Identitas responden adalah aspek penting dalam sebuah penelitian, mengetahui identitas dari responden maka dapat mendeskripsikan secara umum mengenai kondisi

\section{4 | Tingkat Efektivitas Media Penyuluhan Usahatani Kelapa Sawit Kecamatan Pangkalan Kuras Kabupaten Pelalawan}


atau keadaan dan kemampuan dalam melakukan usahatani Karakterisitik responden terdiri dari karakteristik internal dan karakteristik eksternal.

\section{a. Karakteristik Internal}

Tabel 4. Rekapitulasi Karakteristik Internal Petani kelapa sawit di Kecamatan Pangkalan Kuras

\begin{tabular}{llll}
\hline No. & Uraian & Skor & Kategori \\
\hline 1. & Umur & 2,02 & Sedang \\
2. & Tingkat pendidikan & 2,05 & Sedang \\
3. & Luas lahan & 1,85 & Sedang \\
4. $\quad$ Jumlah tanggungan & 1,67 & Sedang \\
5. $\quad$ Pengalaman usahatani & 2,33 & Tinggi \\
6. Pendapatan & 1,77 & Sedang \\
7. $\quad$ Kekosmopolitan & 2,08 & Sedang \\
\hline Jumlah Skor & $\mathbf{1 3 , 7 7}$ & \\
\hline Rata-rata Skor & $\mathbf{1 , 9 7}$ & Sedang \\
\hline
\end{tabular}

Berdasarkan tabel 4 tersebut menunjukkan bahwa petani di Kecamatan Pangkalan Kuras berada dalam kategori sedang dengan skor rata-rata sebesar 1,97. Hal tersebut dikarenakan petani rata-rata berumur 37-48 tahun namun masih dikatakan produktif dengan tingkat pendidikan SMP dan SMA. Pengalaman usahatani petani yaitu 24-30 tahun yang dikategorikan berpengalaman. Luas lahan 2 Ha, dengan pendapatan sebesar UMR Riau. Tingkat kekosmopolitan petani sedang dikarenakan mencari informasi hanya seputar petani, penyuluh, dan media massa seperti koran, jarang mengikuti pelatihan.

Tabel 5. Rekapitulasi karakteristik eksternal petani kelapa sawit di Kecamatan Pangkalan Kuras

\begin{tabular}{lllc}
\hline No. & Uraian & Skor & Kategori \\
\hline 1. & Intensitas Penyuluhan & 1,43 & Rendah \\
2. & Ketepatan saluran penyuluhan & 1,78 & Sedang \\
3. & Jumlah sumber informasi & 1,88 & Sedang \\
4. & Keterjangkauan mengakses & 2,09 & Sedang \\
& sumber informasi & & \\
5. & Ketersediaan saprodi & 1,88 & Sedang \\
6. $\quad$ Ketersediaan sarana penyedia & 1,87 & Sedang \\
7. $\quad$ media & 1,51 & Rendah \\
& Daya dukung lingkungan & 12,44 & - \\
\hline Jumlah Skor & 1,78 & Sedang \\
\hline \multicolumn{2}{l}{-Rata-rata Skor }
\end{tabular}

\section{5 | Tingkat Efektivitas Media Penyuluhan Usahatani Kelapa Sawit Kecamatan Pangkalan Kuras Kabupaten Pelalawan}


Berdasarkan tabel 5 karakteristik eksternal di Kecamatan Pangkalan Kuras termasuk kategori sedang dengan skor rata-rata 1,78. Ketepatan saluran penyuluhan, jumlah sumber informasi, keterjangkauan mengakses sumber informasi, ketersediaan saprodi, ketersediaan sarana penyedia media di Kecamatan Pangkalan Kuras termasuk dalam kategori sedang. Sedangkan intensitas penyuluhan dan daya dukung lingkungan di Kecamatan Pangkalan Kuras termasuk dalam kategori Rendah.

\section{Tingkat Efektivitas Media Penyuluhan}

Menurut Mahmudi (2005), efektivitas merupakan hubungan antara output dengan tujuan, semakin besar kontribusi (sumbangan) output terhadap pencapaian tujuan, maka semakin efektif organisasi, program atau kegiatan atau media yang digunakan.

Tabel 6. Tingkat efektivitas media penyuluhan tercetak di Kecamatan Pangkalan Kuras

\begin{tabular}{llcc}
\hline & \multicolumn{1}{c}{ Media tercetak } & Skor & Kategori \\
\hline 1. & Empathy & 1,91 & Cukup Efektif \\
2. & Persuation & 2,26 & Cukup Efektif \\
3. & Impact & 1,57 & Kurang Efektif \\
4. & Communication & 1,75 & Cukup Efektif \\
\hline & Jumlah skor & 7,49 & \\
\hline & Rata-rata skor & 1,87 & Cukup Efektif \\
\hline
\end{tabular}

Berdasarkan tabel 6 menunjukkan bahwa tingkat efektivitas media penyuluhan tercetak di Kecamatan Pangkalan Kuras berada pada kategori cukup efektif atau dalam skor sebesar 1,87. Media penyuluhan dengan menggunakan media tercetak berupa brosur cukup efektif digunakan dalam melakukan penyuluhan di Kecamatan Pangkalan Kuras, hanya saja sebagian petani mengeluh pada penglihatan yaitu dimana tulisan dalam brosur ukuran kecil dan kurangnya minat baca petani. Hal tersebut menyebabkan rasa empati yang cukup efektif, berdampak pada perubahan sikap dan perilaku yang cukup efektif, dan communication yang cukup efektif. Sehingga kurang efektifnya impact, berdampak kurangnya tingkat pengetahuan petani.

\section{6 | Tingkat Efektivitas Media Penyuluhan Usahatani Kelapa Sawit Kecamatan Pangkalan Kuras Kabupaten Pelalawan}


Tabel 7. Tingkat efektivitas media penyuluhan objek fisik di Kecamatan Pangkalan Kuras

\begin{tabular}{llcc}
\hline No. & Media tercetak & Skor & Kategori \\
\hline 1. & Empathy & 2,59 & Efektif \\
2. & Persuation & 2,55 & Efektif \\
3. & Impact & 2,51 & Efekif \\
4. & Communication & 2,31 & Cukup Efektif \\
\hline & Jumlah skor & 9,96 & \\
\hline & Rata-rata skor & 2,49 & Eektif \\
\hline
\end{tabular}

Berdasarkan tabel 7 menunjukkan bahwa tingkat efektivitas media penyuluhan objek fisik di Kecamatan Pangkalan Kuras berada pada kategori efektif atau dalam skor sebesar 2,49. Media penyuluhan dengan menggunakan media objek fisik berupa penyuluh sebagai media efektif digunakan dalam melakukan penyuluhan di Kecamatan Pangkalan Kuras, hal tersebut dikarenakan tidak terdapat media audio visual yang menunjang dalam kegiatan pelaksanaan penyuluhan. Penyuluh mampu menyesuaikan baik dari materi maupun bahasa dan kondisi petani di desa binaannya. Penyuluh di Kecamatan Pangkalan Kuras bersifat polivalen.

\section{Hubungan Karakteristik Internal Petani dengan Tingkat Efektivitas Media}

Tabel 8. Hubungan karakteristik internal petani kelapa sawit terhadap tingkat efektivitas media tercetak

\begin{tabular}{|c|c|c|c|c|c|c|c|c|}
\hline \multirow{3}{*}{$\begin{array}{l}\text { Karakteristik } \\
\text { Internal }\end{array}$} & \multicolumn{8}{|c|}{ Tingkat Efektivitas Media Tercetak } \\
\hline & \multicolumn{2}{|c|}{ Emphaty (Z1) } & \multicolumn{2}{|c|}{ Persuation $(\mathrm{Z} 2)$} & \multicolumn{2}{|c|}{ Impact (Z3) } & \multicolumn{2}{|c|}{$\begin{array}{l}\text { Communication } \\
\text { (Z4) }\end{array}$} \\
\hline & $\begin{array}{l}\text { Spearma } \\
\text { n's rho }\end{array}$ & Sig. & $\begin{array}{l}\text { Spearma } \\
\text { n's rho }\end{array}$ & Sig. & $\begin{array}{l}\text { Spearm } \\
\text { an's rho }\end{array}$ & Sig. & $\begin{array}{l}\text { Spearma } \\
\text { n's rho }\end{array}$ & Sig. \\
\hline Umur (X1.1) &,- 028 & ,829 &,- 150 &, 254 &,$- 258^{*}$ &, 046 &,- 127 & ,334 \\
\hline Pendidikan (X1.2) &, 111 & ,400 &, 205 &, 116 &, 133 & ,310 &, 076 &, 566 \\
\hline $\begin{array}{ll}\text { Peng. } & \text { Usahatani } \\
\text { (X1.3) } & \end{array}$ &,- 043 & ,747 &,- 140 & ,285 &,- 184 &, 160 &,- 031 &, 815 \\
\hline Luas Lahan (X1.4) &,- 164 & 210 &,- 119 & ,366 &,- 122 &, 351 &,- 015 & ,908 \\
\hline $\begin{array}{l}\text { Jlh. Anggota Kel. } \\
\text { (X1.5) }\end{array}$ &,- 023 & ,860 &,- 074 &, 573 & , 101 & ,441 &, 020 & ,882 \\
\hline Pendapatan (X1.6) &,- 087 &, 508 &,- 074 & ,576 & 015 & ,908 &, 020 & ,881 \\
\hline $\begin{array}{l}\text { Kekosmopolitan } \\
\text { (X1.7) }\end{array}$ & ,143 & ,275 & ,183 &, 163 &, 168 & ,200 & ,146 & ,226 \\
\hline
\end{tabular}

Berdasarkan tabel 8 diatas menunjukkan bahwa hubungan karakteristik internal dengan tingkat efektivitas media tercetak rata-rata berkorelasi sangat rendah, hanya

\section{7 | Tingkat Efektivitas Media Penyuluhan Usahatani Kelapa Sawit Kecamatan Pangkalan Kuras Kabupaten Pelalawan}


saja umur dengan impact berkorelasi rendah. Hal ini dari hasil analisis Rank Spearman adalah $\mathrm{r}_{\mathrm{s}}=-0,258^{*}$. Kedua sub-variabel ini mempunyai hubungan yang negatif. Hal tersebut mengartikan bahwa umur berhubungan dengan impact, akan tetapi umur yang besar ada kecenderungan kurang meningkat pengetahuannya setelah menerima pesan dari media tercetak seperti brosur. Hal tersebut dikarenakan tingkat efektivitas media tercetak dalam kategori cukup efektif, dan faktor lain seperti minat baca yang kurang, masalah penglihatan, dan daya serap terhadap suatu informasi atau materi yang mulai berkurang dikarenakan faktor umur yang dikategorikansedang. Tabel 9. Hubungan karakteristik internal petani kelapa sawit terhadap tingkat efektivitas media objek fisik

\begin{tabular}{|c|c|c|c|c|c|c|c|c|}
\hline \multirow{3}{*}{$\begin{array}{l}\text { Karakteristik } \\
\text { Internal }\end{array}$} & \multicolumn{8}{|c|}{ Tingkat Efektivitas Media Objek Fisik } \\
\hline & \multicolumn{2}{|c|}{ Emphaty (Z1) } & \multicolumn{2}{|c|}{ Persuation (Z2) } & \multicolumn{2}{|c|}{ Impact (Z3) } & \multicolumn{2}{|c|}{$\begin{array}{l}\text { Communication } \\
\text { (Z4) }\end{array}$} \\
\hline & $\begin{array}{l}\text { Spearma } \\
\text { n's rho }\end{array}$ & Sig. & $\begin{array}{l}\text { Spearma } \\
\text { n's rho }\end{array}$ & Sig. & $\begin{array}{l}\text { Spearm } \\
\text { an's rho }\end{array}$ & Sig. & $\begin{array}{l}\text { Spearm } \\
\text { an's rho }\end{array}$ & Sig. \\
\hline Umur (X1.1) & ,082 & ,535 &,$- 267 *$ & ,039 &,- 093 & ,478 &,- 159 & ,224 \\
\hline Pendidikan (X1.2) & 067 & 609 &, 129 & ,327 & 094 & ,476 &, 171 & , 192 \\
\hline $\begin{array}{l}\text { Peng. } \quad \text { Usahatani } \\
\text { (X1.3) }\end{array}$ & ,098 & , 454 &,- 191 & ,144 &,- 168 & ,200 &,- 140 & ,286 \\
\hline $\begin{array}{ll}\text { Luas } & \text { Lahan } \\
\text { (X1.4) } & \end{array}$ &, 021 & ,871 &,- 116 & ,376 &, 057 & ,667 &,- 164 & ,210 \\
\hline $\begin{array}{l}\text { Jlh. Anggota Kel. } \\
\text { (X1.5) }\end{array}$ & ,060 & ,651 & , 105 & ,426 & ,022 & ,868 & -.054 & ,683 \\
\hline Pendapatan (X1.6) &,- 058 & ,662 & ,019 & ,884 &,- 037 & ,779 &,- 193 & ,139 \\
\hline $\begin{array}{l}\text { Kekosmopolitan } \\
\text { (X1.7) }\end{array}$ &,- 007 & 961 &, 173 & ,187 &,- 081 &, 539 & ,146 & ,226 \\
\hline
\end{tabular}

Berdasarkan tabel 9 diatas menunjukkan bahwa hubungan karakteristik internal dengan tingkat efektivitas media objek fisik rata-rata berkorelasi sangat rendah, hanya saja umur dengan persuation berkorelasi rendah. Hal ini terlihat dari dari hasil analisis Rank Spearman adalah $\mathrm{r}_{\mathrm{s}}=-0,267^{*}$. Kedua sub-variabel ini mempunyai hubungan yang negatif. Hal tersebut mengartikan bahwa petani yang memiliki umur yang bertambah tua ada kecenderungan sulit mengalami perubahan sikap dan perilaku petani dalam berusahatani kelapa sawit setelah adanya penyuluh sebagai media dalam penyuluhan. Hal tersebut dikarenakan petani terbiasa melakukan kegiatan usahatani berdasarkan kebiasaan turun temurun yang dilakukan oleh

\section{8 | Tingkat Efektivitas Media Penyuluhan Usahatani Kelapa Sawit Kecamatan Pangkalan Kuras Kabupaten Pelalawan}


keluarganya dan tingkat efektivitas media objek fisik yang efektif dilaksanakan di Kecamatan Pangkalan Kuras.

\section{Hubungan Karakteristik Eksternal Petani dengan Tingkat Efektivitas Media}

Tabel 10. Hubungan karakteristik eksternal petani kelapa sawit terhadap tingkat efektivitas media tercetak

\begin{tabular}{|c|c|c|c|c|c|c|c|c|}
\hline \multirow{3}{*}{ Karakteristik Eksternal } & \multicolumn{8}{|c|}{ Tingkat Efektivitas Media Tercetak } \\
\hline & \multicolumn{2}{|c|}{ Emphaty (Z1) } & \multicolumn{2}{|c|}{ Persuation (Z2) } & \multicolumn{2}{|c|}{ Impact (Z3) } & \multicolumn{2}{|c|}{$\begin{array}{l}\text { Communicatio } \\
\mathrm{n}(\mathrm{Z} 4)\end{array}$} \\
\hline & $\begin{array}{l}\text { Spearm } \\
\text { an's rho }\end{array}$ & Sig. & $\begin{array}{l}\text { Spear } \\
\text { man's } \\
\text { rho }\end{array}$ & Sig. & $\begin{array}{l}\text { Spear } \\
\text { man's } \\
\text { rho }\end{array}$ & Sig. & $\begin{array}{l}\text { Spear } \\
\text { man's } \\
\text { rho }\end{array}$ & Sig. \\
\hline $\begin{array}{lr}\text { Intensitas } & \text { Penyuluhan } \\
\text { (X2.1) } & \\
\text { Ketepatan } & \text { Saluran }\end{array}$ &, 060 & ,649 &, 139 & ,289 &, 158 & ,226 &, 126 & ,338 \\
\hline Penyuluhan (X2.2) & 223 & 086 & 230 & ,077 &, 178 & 173 &, 178 &, 173 \\
\hline $\begin{array}{l}\text { Jlh. Sumber Informasi } \\
\text { (X2.3) }\end{array}$ &, 242 &, 062 &, $261 *$ &, 044 &, 138 & ,294 &, 125 & ,343 \\
\hline $\begin{array}{l}\text { Keterjangkauan Mengakses } \\
\text { Sumber Informasi (X2.4) }\end{array}$ &,- 023 & 864 &,- 085 &, 518 &,- 036 & ,786 & 021 &, 872 \\
\hline $\begin{array}{l}\text { Ketersediaan } \\
\text { (X2.5) }\end{array}$ &,- 097 & ,459 &,- 020 &, 881 &, 009 & ,948 &,- 033 &, 804 \\
\hline Ketersediaan & & & & & & & & \\
\hline Penyedia Media (X2.6) &,- 022 & ,866 & 087 &, 509 &, 152 & ,246 & ,086 &, 513 \\
\hline $\begin{array}{l}\text { Daya Dukung Lingkunga } \\
\text { (X2.7) }\end{array}$ & ,241 &, 063 &, 051 &, 702 &, $300 *$ &, 020 &,- 106 & ,421 \\
\hline
\end{tabular}

Berdasarkan tabel 10 diatas menunjukkan bahwa hubungan karakteristik eksternal dengan tingkat efektivitas media tercetak rata-rata berkorelasi sangat rendah. Terdapat hubungan antara jumlah sumber informasi dan daya dukung lingkungan dengan tingkat efektivitas media yang meliputi persuation, dan impact. Kekuatan hubungan jumlah sumber informasi dengan persuation dilihat dari hasil analisis Rank Spearman adalah $\mathrm{r}_{\mathrm{s}}=0,261^{*}$, mengindikasikan bahwa hubungan ini berada pada kategori korelasi rendah. Kedua sub-variabel ini mempunyai hubungan yang positif. Hal tersebut mengartikan bahwa semakin banyak jumlah sumber informasi yang diperoleh petani dari media tercetak seperti berosur maka ada kecenderungan semakin banyak informasi yang diperoleh petani dan berpengaruh pada perubahan sikap dan perilaku petani sendiri.

Kekuatan hubungan daya dukung lingkungan dengan impact dilihat dari hasil analisis Rank Spearman adalah $\mathrm{r}_{\mathrm{s}}=0,300^{*}$, mengindikasikan bahwa hubungan ini

\section{9 | Tingkat Efektivitas Media Penyuluhan Usahatani Kelapa Sawit Kecamatan Pangkalan Kuras Kabupaten Pelalawan}


berada pada kategori korelasi rendah. Kedua sub-variabel ini mempunyai hubungan yang positif. Hal tersebut mengartikan bahwa semakin baik daya dukung lingkungan petani maka ada kecenderungan berdampak pada diri petani dengan meningkatnya pengetahuan petani sendiri, Hal tersebut di dukung adanya jaringan internet yang memadai dan lingkungan sekitar yang menggunakan handphone maupun smartphone yang digunakan untuk mencari informasi maupun berkomunikasi.

Tabel 11. Hubungan karakteristik eksternal petani kelapa sawit terhadap tingkat efektivitas media objek fisik

\begin{tabular}{|c|c|c|c|c|c|c|c|c|}
\hline \multirow{3}{*}{$\begin{array}{l}\text { Karakteristik } \\
\text { Eksternal }\end{array}$} & \multicolumn{8}{|c|}{ Tingkat Efektivitas Media Objek Fisik } \\
\hline & \multicolumn{2}{|c|}{ Emphaty (Z1) } & \multicolumn{2}{|c|}{ Persuation (Z2) } & \multicolumn{2}{|c|}{ Impact (Z3) } & \multicolumn{2}{|c|}{$\begin{array}{l}\text { Communication } \\
\text { (Z4) }\end{array}$} \\
\hline & $\begin{array}{l}\text { Spear } \\
\text { man's } \\
\text { rho }\end{array}$ & Sig. & $\begin{array}{l}\text { Spear } \\
\text { man's } \\
\text { rho }\end{array}$ & Sig. & $\begin{array}{l}\text { Spearm } \\
\text { an's rho }\end{array}$ & Sig. & $\begin{array}{l}\text { Spearma } \\
\text { n's rho }\end{array}$ & Sig. \\
\hline $\begin{array}{l}\text { Intensitas Penyuluhan } \\
\text { (X2.1) } \\
\text { Ketenatan Saluran }\end{array}$ &,- 137 & ,295 &,- 027 &, 838 &, 016 & ,904 & ,046 & ,727 \\
\hline Penyuluhan (X2.2) &,- 181 & , 167 &,- 212 &, 104 &, 053 & ,688 &, 044 & ,740 \\
\hline $\begin{array}{l}\text { Jlh. Sumber } \\
\text { Informasi (X2.3) } \\
\text { Keterjangkauan }\end{array}$ &, 085 &, 518 & ,033 & ,801 &, 144 &, 272 &, 115 & ,382 \\
\hline Mengakses Sumber & & & & & & & & \\
\hline Informasi (X2.4) &, 084 &, 525 & ,042 &, 753 &, 007 & ,956 &, 230 & ,078 \\
\hline $\begin{array}{l}\text { Ketersediaan } \\
\text { (X2.5) }\end{array}$ &,- 106 & ,419 &, 108 & ,410 &,- 132 & ,315 &, $256^{*}$ & ,048 \\
\hline $\begin{array}{ll}\text { Penyedia } & \text { Media } \\
\text { (X2.6) } & \\
\text { Daya } & \text { Dukung }\end{array}$ &, 008 & ,950 &, 123 &, 350 &,- 077 &, 557 &,- 060 & ,651 \\
\hline Lingkungan (X2.7) &, 102 & ,437 & ,037 &, 778 &,- 078 & ,554 &, 013 & ,921 \\
\hline
\end{tabular}

Berdasarkan tabel 11 diatas menunjukkan bahwa hubungan karakteristik eksternal dengan tingkat efektivitas media objek fisik rata-rata berkorelasi sangat rendah. Terdapat hubungan antara ketersediaan saprodi dengan tingkat efektivitas media yang meliputi communication. Kekuatan hubungan ketersediaan saprodi dengan communication dilihat dari hasil analisis Rank Spearman adalah $\mathrm{r}_{\mathrm{s}}=0,256^{*}$, mengindikasikan bahwa hubungan ini berada pada kategori korelasi rendah. Kedua sub-variabel ini mempunyai hubungan yang positif. Hal tersebut mengartikan bahwa semakin banyak ketersediaan saprodi petani kelapa sawit ada kecenderungan komunikasi dan tingkat pemahaman yang baik petani kelapa sawit dengan media

\section{0 | Tingkat Efektivitas Media Penyuluhan Usahatani Kelapa Sawit Kecamatan Pangkalan Kuras Kabupaten Pelalawan}


objek fisik yaitu penyuluh. Saprodi di Kecamatan Pangkalan kuras jelas tersedia hal tersebut dikarenakan banyaknya toko yang menjual saprodi, dan adanya bantuan pupuk dari pemerintsah.

\section{KESIMPULAN}

\section{Kesimpulan}

Berdasarkan hasil penelitian yang dilakukan dapat diambil kesimpulan sebagai berikut:

1. Tingkat efektivitas media penyuluhan di Kecamatan Pangkalan Kuras Kabupaten Pelalawan terdiri dari media tercetak dan media objek fisik. Media tercetak berupa brosur berada pada kategori cukup efektif, sedangkan media objek fisik berada pada kategori efektif. Hal tersebut menunjukkan bahwa penyuluh sebagai media objek fisik efektif digunakan pada Desa Surya Indah dan Desa Dundangan.

2. Hubungan karakteristik internal dengan tingkat efektivitas media tercetak dan objek fisik rata-rata berkorelasi sangat rendah. Pada media tercetak umur berhubungan dengan impact, akan tetapi umur yang besar ada kecenderungan kurang meningkat pengetahuannya setelah menerima pesan dari media tercetak seperti brosur. Hal tersebut dikarenakan tingkat efektivitas media tercetak dalam kategori cukup efektif. Pada media objek fisik umur dengan persuation . Hal tersebut mengartikan bahwa petani yang memiliki umur yang bertambah tua ada kecenderungan sulit mengalami perubahan sikap dan perilaku petani dalam berusahatani kelapa sawit setelah adanya penyuluh sebagai media dalam penyuluhan. Hubungan karakteristik eksternal dengan tingkat efektivitas media tercetak dan objek fisik rata-rata berkorelasi sangat rendah. Pada media tercetak korelasi tersebut antara daya dukung lingkungan dengan impact, Hal tersebut mengartikan bahwa semakin banyak jumlah sumber informasi yang diperoleh petani dari media tercetak seperti berosur maka ada kecenderungan semakin banyak informasi yang diperoleh petani dan berpengaruh pada perubahan sikap dan perilaku petani sendiri. Pada media objek fisik korelasi tersebut antara

\section{1 | Tingkat Efektivitas Media Penyuluhan Usahatani Kelapa Sawit Kecamatan Pangkalan Kuras Kabupaten Pelalawan}


ketersediaan saprodi dengan communication, hal tersebut mengartikan bahwa semakin banyak ketersediaan saprodi petani kelapa sawit ada kecenderungan komunikasi dan tingkat pemahaman yang baik petani kelapa sawit dengan media objek fisik yaitu penyuluh.

\section{DAFTAR PUSTAKA}

Akdon, dan Sahlan M.T. 2007. Aplikasi Statistika Dan Metode Untuk Penelitian

Administrasi Dan Manajemen. Dewa Ruche. Bandung

Badan Pusat Statistik. 2016. Pelalawan dalam Angka. Pelalawan

Dinas Perkebunan Dan Kehutanan Kabupaten Pelalawan. 2018. Statistik Perkebunan Pelalawan 2017. Pelalawan. Riau.

Dinas Perkebunan Provinsi Riau. 2016. Provinsi Riau Dalam Angka 2017. Riau

Durianto, dkk. 2003. Invasi Pasar dengan Iklan yang Efektif. PT. Gramedia Pustaka Utama: Jakarta

Herzberg, F. 1990. “One More Time: How Do You Motivate Employers?" Harvard Business Review, p. 85.

Mahmudi. 2005. Manajemen Kinerja Sektor Publik. PT. Gramedia. Jakarta Negara, M.senopati. 2010. Analisis Persepsi Perbandingan Efektivitas Iklan Tv : Yamaha Mio Dan Honda Vario (Studi Kasus FEB UIN Syarif Hidayatullah). Univesitas Islam Negri Syarif Hidayatullah. Jakarta.

Riduan. 2011. Rumus dan Data dalam Analisis Statistika. Alfabeta. Bandung.

Siagian Sondang P. 2002. Kiat Meningkatkan Produktivitas Kerja, Cetakan Pertama. PT. Rineka Cipta: Jakarta 